\title{
Developing of Problem-Based Learning Devices to Teach Numbers Pattern Materials
}

\author{
Felni Gemma Nucifera Womboiang*, Santje Salajang, Aaltje Pangemanan \\ Study program of Mathematics Education \\ State University of Manado \\ Manado, Indonesia \\ *felninucifera@gmail.com, santjesalajang@unima.ac.id, aaltjepangemanan@unima.ac.id
}

\begin{abstract}
The purpose of this research is to produce a Mathematical Learning Devices Model Problem based learning to Teach Numbers Pattern Material, which fulfills valid, practical, and effective criteria. This research method is categorized as development research. The sample in this study was an eighth grade students of Junior High Scholl state 3 Tondano. In this research the lesson plan (RPP), student worksheet (LKPD), and learning outcome evaluation (EHB) were developed using the problem based learning model. The results of this study show that the products developed met valid, practical, and effective criteria. Learning devices are feasible to use based on the evaluation of learning devices by the validator with an average score of 3.9 categorized as valid. The practicality results of the learning kit were obtained from the student response questionnaire which showed that the developed device met the practical criteria to be used as learning source. The effectiveness evaluation indicates that the use of the developed device improves students' mastery learning Students above the average score, suggesting that the learning device is effectively used in teaching mathematics.
\end{abstract}

Keywords: problem-based learning, development, learning devices, number pattern

\section{INTRODUCTION}

Education in the times has always provided innovations that can create an interesting learning process. One of the developments in the world of education is curriculum change, in which there are four substantial curriculum development goals: (1) reconstructing the previous curriculum, (2) innovating, (3) adapting to social change (the positive side), (4) exploring knowledge that still hidden based on national education goals that have been formulated.

From the curriculum development, it must be rooted, but it must also be tall, tall, leafy and leafy. Rooted means sticking to the nation's philosophy and looming means following the changes and developments of the times [1]. The learning process in the 2013 curriculum emphasizes the principle of active student learning. In a learning activity, active students mean that there is something that makes them interested in learning.

Mathematics is one of the subjects that must be studied in schools that can equip students with the ability to think logically, analysis, systematic, critical and creative as well as the ability to cooperate. Problem solving in mathematics is certain, so that it is used as a learning goal to measure students' mathematical problem solving abilities.

Indicators of mathematical problem solving Students according to the 2013 curriculum include: (1) Understanding problems, (2) Organizing data and selecting relevant information in identifying problems, (3) Presenting a mathematical problem formulation in various forms, (4) Choosing approaches and strategies appropriate for solving problems, (5) Using or developing problem solving strategies, (6) Interpreting the results of answers obtained to solve problems, (7) Resolving problems.

However, mathematics itself is often shunned or hated for reasons of using too many formulas, also learning that does not make students interested which results in low student learning outcomes because they answer carelessly or do not answer. Meanwhile, the development of technology now cannot be rejected, so every individual inevitably has to follow trends. Likewise, Students, Students prefer something that is instant and fast without going to bother or try first.

As a teacher, it is a big challenge in creating creative and fun teaching and learning activities. Behavior Students are found in class who are busy with their respective activities while in math class. So that students look less active and less enthusiastic, and learning is not considered a fun activity, this has an impact on low learning outcomes.

In addition, in a survey of mathematics teachers at Tondano 3 Public Middle School, with 210 students, there were only 2 mathematics teachers in the school while there were 7 classes with classes VII and IX each having 2 classes, so the division was wrong one teacher holds 4 classes for mathematics.

From the series of learning devices used by teachers include: Syllabus, Lesson Plan (RPP), Annual Program, Semester Program, Mastery Learning (KKM), Basic Competencies (KD) Mapping, Learning Outcomes (SKL), Value List, Core Competence-Basic competence (KI-KD) Analysis, Gender Education, and so on. Another reason is the number of teaching hours, there are also activities that are not scheduled, so that teachers are to immediately complete the 
learning kit, done by copy-paste from the previous curriculum learning kit, and the phases follow the existing examples.

While this learning devices should be arranged as well as possible by the teacher based on the situation and conditions in the classroom, and even then the activity may not run properly. But because the condition of the teacher is only 2 people this of course makes the teacher overwhelmed. So in this case the learning device is really not modified, so the learning style is just like that. Even today the development of learning devices can be easily obtained even some are making it a business.

In particular, the Lesson Plan, or in Indonesian is Rencana Pelaksanaan Pembelajaran (RPP) and Student Worksheet or in Indonesian is Lembar Kerja Peserta Didik (LKPD) not many teachers have developed it, most use the RPP and LKPD that are available on the internet so they just need to download it, some develop it only when they need supervision or to follow activities that require using RPP. There are 3 learning models used in the 2013 Curriculum.

On the teacher's handbook in the lesson plan is also found to include the use of learning models, with the aim that there is innovation in learning activities. In fact the use of learning models is only included in the lesson plan, in the process it returns to the way of teaching and learning in one direction.

Number Pattern Material is one of the subjects studied in class VIII of junior high school. This material is the easiest material for some people, but at the junior high school level the reality is that students still have difficulty in solving material number problems. This material can use problems in the real world so that it fits with the learning model that links a learning activity that is based on problems from the real world, so students will better understand and will not be confused anymore to solve the material problems of number patterns.

Therefore, in order to help students, overcome these problems, the authors are interested in developing learning devices in the form of RPP, LKPD and Learning Outcomes Evaluation or in Indonesian is Evaluasi Hasil Belajar (EHB) that can make learning mathematics enjoyable and can foster student interest in learning. One way to attract students' interest in learning is to use examples or problems in the real world that are close to their lives, so that they will indirectly think and be interested in the topics discussed.

Problem Based Learning is one of the learning models that brings real world problems into the learning process and allows students to learn in groups and can see their interactions in the group, so that it can activate the function of peers for students who are ashamed to ask the teacher, also can be assessed how Students' ability to convey information to their group friends.

Student success depends on 21 st century skills, so students must have it. These skills include the ability to solve problems (problem solving), critical thinking (critical thinking), collaboration, and communication skills. All of these skills can be possessed by students if the educator is able to develop a learning plan that contains activities that challenge students to think critically in solving problems.
Activities that encourage students to work together and communicate must appear in every learning plan they make [2]. One solution to improve the quality of mathematics learning is that teachers can prepare and develop appropriate learning through the use of Problem Based Learning (PBL) models that are applied to the development of learning devices such as RPP, LKPD, and EHB in accordance with the stages of the PBL model.

PBL is an instructional method that challenges students to learn to learn, work together in groups to find learning with real-world problems [3]. By using the PBL model a learning devices will be developed that can attract students' interest to learn, also students can arrange their own concepts and better understand the lesson in their own way which will affect their learning outcomes later.

In addition, learning devices with the Problem Based Learning model on the subject of number patterns for Class VIII students that are in accordance with the 2013 curriculum have not been developed. So that in this study LKPD was developed based on the aspects of content eligibility, presentation, graphics and language. While the RPP will be developed based on the principle of developing the RPP as stated in Permendikbud number 69 of 2013.

In connection with the learning devices that must be prepared by the teacher when teaching in class, then in this study developed is a learning device to develop the concept of Number Patterns using problem based learning models in Class VIII students which include: lesson plan (RPP), Students worksheet (LKPD), and learning outcome evaluation (EHB).

\section{METHODS}

The method used in this study was research development. Model used to develop learning devices in this study is a modification of the Thiagarajan model known as the Four-D Models (Model 4D) [4], which are defining, designing, developing, and disseminating. Researchers modify the development model with a simplified model that is limited to the development stage with consideration of the limited time and cost. Research sites is 8th grade students at SMP Negeri 3 Tondano. The data collection used from student outcomes, questionnaire, and documents. Then data were analyzed with criteria of validity, practicality, and effectiveness [5].

\section{RESULTS AND DISCUSSION}

\section{A. Validity of Lesson Plan (RPP), Student Worksheet (LKPD), and Learning Outcome Evaluation (EHB)}

The RPP that has been developed is validated by the validator. This validation is done to determine the validity of the lesson plan before the simulation and trial can be seen in table I. 
TABLE I. V VALIDITY OF THE LESSON PLAN (RPP)

\begin{tabular}{|c|c|c|}
\hline Elements & Mean & Category \\
\hline Format & 4,2 & \\
\hline Purpose & 4,2 & \\
\hline Subject matter & 3,75 & \\
\hline Assessment & 3,6 & \\
\hline Learning activity & 3,6 & \\
\hline Language and writing & 3,9 & \\
\hline Time Allocation & 4 & \\
\hline Usability benefits & 4 & \\
\hline Average Total & 3,91 & Very valid \\
\hline
\end{tabular}

Table 1 showed that the RPP is validated by three expert lecturers, one mathematics teacher, and one classmate. Based on the validator's assessment, the average total analysis result of the RPP assessment is 3.91 which means it is very valid.

\section{B. Validity Of LKPD}

LKPD that has been developed is validated by a validator. This validation was conducted to determine the validity of the LKPD prior to the simulation and trial can be seen in table II.

TABLE II. VALIDITY OF THE STUDENT WORKSHEET (LKPD)

\begin{tabular}{|l|l|l|}
\hline \multicolumn{1}{|c|}{ Elements } & Mean & \multirow{2}{*}{ Category } \\
\hline Format & 4,03 & \\
\hline content & 3,69 & \\
\hline Assessment diagram, and & 3,76 & \\
\cline { 1 - 2 } $\begin{array}{l}\text { Illustration, table, } \\
\text { picture layout }\end{array}$ & \multirow{2}{|c|}{} \\
\cline { 1 - 2 } Usability benefits & 3,7 & \\
\hline \multicolumn{1}{|c|}{ Average Total } & $\mathbf{3 , 8 1}$ & Very valid \\
\hline
\end{tabular}

Table 2 showed that the LKPD was validated by three expert lecturers and one mathematics teacher. Based on the validator's assessment, the average total analysis result of the RPP assessment is 3.81 which means it is very valid.

\section{Practicality of Student Response Questionnaire, and Teacher Ability to Manage Learning}

Based on data from the Student response questionnaire that has been filled out by 24 Students after participating in learning activities for material number patterns with a problem based learning model, can be seen in table 3 and 4 .

TABLE III. STUDENT RESPONSE ON THE QUESTIONNAIRE

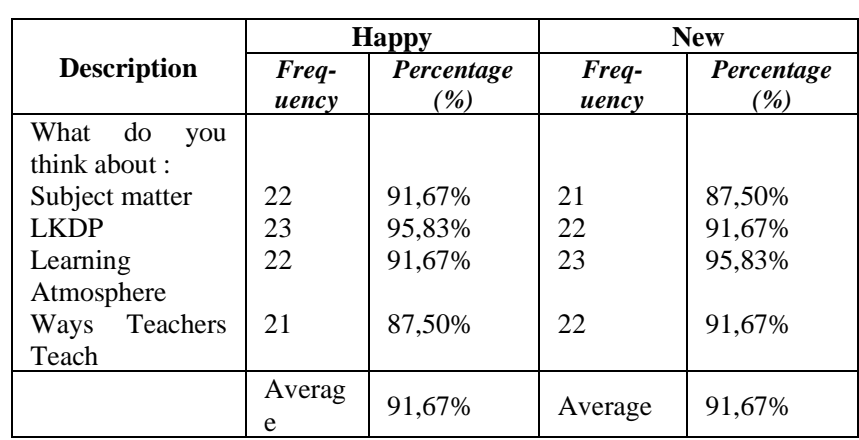

Table 3. Cont.

\begin{tabular}{|l|l|l|}
\hline \multicolumn{1}{|c|}{ Description } & \multicolumn{2}{|c|}{ Agree } \\
\cline { 2 - 3 } & \multicolumn{1}{|c|}{ Frequency } & Percentage (\%) \\
\hline $\begin{array}{l}\text { Your opinion if } \\
\text { the next subject } \\
\text { uses learning like } \\
\text { this }\end{array}$ & & $91,67 \%$ \\
$\begin{array}{l}\text { Your opinion if } \\
\text { all subjects use } \\
\text { learning like this }\end{array}$ & 20 & $83,33 \%$ \\
\hline & Average & $87,50 \%$ \\
\hline
\end{tabular}

It can be said that student responses to all aspects are above $80 \%$. Then every aspect responded positively by students.

TABLE IV. TEACHER ABILITY TO MANAGE LEARNING

\begin{tabular}{|c|c|c|}
\hline Elements & Mean & Category \\
\hline Preliminary & 3,8 & \\
\hline Student orientation to problems & 4 & \\
\hline Organizing student learning & 4 & \\
\hline Guide group investigations & 4 & \\
\hline Develop and present the work & 3,67 & \\
\hline $\begin{array}{l}\text { Analyze and evaluate the problem } \\
\text { solving process }\end{array}$ & 3,83 & \\
\hline $\begin{array}{c}\text { Average Total } \\
\end{array}$ & 3,84 & Very valid \\
\hline
\end{tabular}

Based on the criteria of the teacher's ability to manage learning, the average total analysis result of the teacher's ability to manage learning is 3.71 and reaches the "good" category, located at intervals $3 \leq \mathrm{P}<4$.

\section{Effectiveness of Student Activity and Mastery of Student \\ Learning Outcomes}

Observation on students' activities during learning activities appear that Student activities during learning are met the criteria of effectiveness. It is showed by the percentage of students' participation at each criteria that met good criteria, such as listening on teacher explanation (13.26\%), reading comprehension (15.79\%), doing task (36.48\%), ability to make conclusion (16.45\%), and doing bad behavior (0.2\%).

Analysis on students' mastery learning were evaluated using the learning outcome test (EHB). The results showed in detail in Table 5.

TABLE V. STUDENT LEARNING OUTCOMES

\begin{tabular}{|l|l|l|l|l|}
\hline $\begin{array}{c}\text { The } \\
\text { number } \\
\text { of } \\
\text { students }\end{array}$ & $\begin{array}{c}\text { Number of } \\
\text { Students } \\
\text { Completed }\end{array}$ & $\begin{array}{c}\text { Percentage } \\
\text { of } \\
\text { completeness }\end{array}$ & $\begin{array}{c}\text { Number } \\
\text { of } \\
\text { Students } \\
\text { who Did } \\
\text { Not } \\
\text { Complete }\end{array}$ & $\begin{array}{c}\text { Percentage of } \\
\text { incompleteness }\end{array}$ \\
\hline 24 & 21 & $87,5 \%$ & 3 & 12,5 \\
\hline
\end{tabular}

It can be seen in Table $\mathrm{V}$ that the percentage of the number of students who reach completeness is included in the very good criteria with a percentage of $87.5 \%$. This shows that learning devices developed after effective use in learning activities. The learning devices developed "Valid" based on expert validation, said "Practical" if it was easy and the management of learning could be carried out by teachers who 
SMP Negeri 3 Tondano can be said to be effective this

were categorized well and questionnaire responses of students towards positive learning. "Effectiveness" of learning devices obtained through the Evaluation of Mathematics Learning Outcomes provided to Students, based on the analysis of learning outcomes seen that the percentage of students who achieve mastery is included in the criteria either.

Thus, mathematics learning devices model of problem based learning has been produced to teach the number pattern material in class VIII of SMP Negeri 3 Tondano. The learning devices produced include RPP, LKPD, and EHB.

\section{CONCLUSION}

- Mathematical learning devices model of problem based learning to teach material number patterns were developed using a modified 4-D development model, resulting in a valid learning devices for material number patterns in the problem based learning model. Learning devices developed include: lesson plans, Student activity sheets, and evaluation of learning outcomes.

- The learning device is said to be practical for teaching material number patterns using problem based learning models, this is shown from the observation of the teacher's ability to manage learning and Student responses to positive learning.

- Mathematics learning uses problem based learning models to teach material pattern numbers in class VIII shows by analyzing the activities of students categorized well and student learning outcomes are complete.

- Mastery learning Students at EHB shows the percentage of students who complete $>80 \%$, students complete individually.

- Student responses positive to the learning process completed by the learning device.

\section{REFERENCES}

[1] B. Syamsul, "Basic Curriculum Development and Its Purpose," Futura Islamic Scientific Journal, vol. 11, no. 1, pp. 32, 2011.

[2] I. Rafianti, "Development of Mathematics Learning devices in Supporting 21st Century Ability," Kalamatics Journal of Mathematics Education, vol. 3, no. 2, pp. 125-126, 2018.

[3] M. Amir, T. Taufiq, Educational Innovation through Problem Based Learning How Educators Empower Students in the Knowledge Age. Jakarta: Prenada Media Group, 2010.

[4] S. Thiagarajan, Instructional development for training teachers of exceptional children: A sourcebook, 1974.

[5] E. Syahputra and E. Surya, "The Development of Learning Model Based on Problem Solving to Construct High-Order Thinking Skill on the Learning Mathematics of 11th Grade in SMA/MA," Journal of Education and Practice, vol. 8, no. 6, pp. 80-85, 2017. 